\title{
Electronic Accounting Practices: An Effective Means for Financial Reporting Quality in Nigeria Deposit Money Banks.
}

\author{
Oladejo, M.O ${ }^{1^{*}}$, Yinus S.O' \\ ${ }^{I}$ Department of Management and Accounting, LadokeAkintola University of Technology Ogbomoso, Oyo State, \\ Nigeria. \\ ${ }^{2}$ School of E-Learning Project,Kampala International University, Kampala, Uganda.
}

*Corresponding Author:Oladejo, M.O,Department of Management and Accounting, LadokeAkintola

\begin{abstract}
Nigerian banking industry has in recent times been reportedly facing different degrees of financial issues which give rise to widespread failure in the financial information quality. This serves as a pointer to the relevance of electronic accounting practices in achieving global quality financial reporting. Electronic accounting practice is a technology-based method which combines accounting principles as well as the concept of an information system to record, process, analyze and produce financial information about a business to end users. Studies in this regard, focusing on Nigeria Money Deposit Banks (NDMBs) were few and require further empirical investigation. This study, therefore, evaluated the impact of e-accounting practices on financial reporting quality of selected banks in Nigeria. Primary data were collected using questionnaire and secondary data covering a period of 2010-2017 were collected from the annual report of the selected banks. Ten deposit money banks in Nigeria were selected using homogeneous purposive sampling. Three hundred copies of a questionnaire were administered randomly on the selected staff of the banks out of which two hundred and sixty were returned and used for the study. Data collected were analysed using descriptive statistics like table and percentage with inferential statistics such as pooled regression analysis at 95\% confidence level. The results showed that Bank Size (BS) at 92\%; Cost of ICT Deployment (CID) at 69\%; Perceived Ease of Use (PEOU) at 74\%; and Perceived Benefit (PB) at 86\% were specific factors influencing electronic accounting adoption in the selected banks. A significant differences was observed in factor influencing e-accounting adoption $\left(R^{2}=0.9661 ; \operatorname{Adj} R^{2}=0.9633 ; F=1318.61 ; p=0.000\right)$. The fixed effect estimation result revealed that electronic accounting promotes users confidence on the financial statement of the selected banks $\left(R^{2}=0.6203 ;\right.$ Adj $\left.R^{2}=0.6150 ; \quad F=67.20 ; p=0.000\right)$. This study concluded that all the considered variables; $B S, C I D, P E O U$, and PB influenced e-accounting adoption and that e-accounting practice enhanced accounting procedure and improved the timeliness of report generation and financial reporting quality of banks. It was recommended that deposit money banks should put more effort by developing mechanism that strengthens e-accounting usage to promote users confidence on the financial information published by banks.
\end{abstract}

Keywords:Financial reporting System, Users Confidence, Financial Information, E-accounting Practice,

\section{INTRODUCTION}

Evidence from the literature (Akinduko, 2000; Anao, 2002; Emmanuel, 2015) revealed that the major reason for accounting practice is to ascertain financial position at a given time. Accounting information system (AIS) is useful in all types of organizations especially the banking industry where the survival and growth of such organization depend to a large extent, on supplying effective accounting information to internal and external users (Khalid, 2004).It is also apt to contend that the size of an organization determines the appropriate volume and complexity of accounting information for managerial decisions in such areas as purchasing, protection, hiring, borrowing, and investment. For instance, Amidu,Effar, and Abor, (2011) averred that accounting systems are responsible for recording, analyzing, monitoring and evaluating the financial condition of companies, preparation of documents necessary for tax purposes, providing information support to many other organizational functions, and so on.

The objective of accounting information systems is to provide the reliable accounting information on a timely basis (Guan, 2006). An internal control system is a series of procedures designed such that 
provide management with reasonable assurance that the accounting information that provide by an accounting information system presents is reliable and made available timely (Guan, 2006). Accounting information system is a collection of data and processing procedures that creates needed information for its users (Bagranof et al, 2011). More so, the quality of accounting information comes from the implementation of an accounting information systems quality. Among of author use different terminologies when describing the quality of accounting information system, such as: effectiveness, success, usefulness, efficiency, user satisfaction, and also the term of quality itself. Gelinas, Sutton and Hunton (2005) suggests that the effectiveness of AIS is a measure of an accounting information system success to meet the established goals.

Scholars in the field of accounting (Abeysekera, 2013;Adeyemi and Asaolu, 2014; Abraham and Shrives, 2014) revealed that to determine the effectiveness of a financial reporting system, one must understand accounting information objectives and its relevance with different accounting standards. In this wise, a good accounting information system is expected to aid the reporting quality and hence promote user confidence in the financial statement. This is because the financial statement is one of the sources of information that produce financial information to interested parties (Yen and Nuraini, 2016). With this, a standard that can report accurate accounting information is expected from financial reporting. Literature on financial accounting as observed by Jacob and Madu (2009); Higson (2003) revealed that financial information stated in financial statements is an avenue for the corporate firm to communicate their internal and external users on financial position the firm, financial information should be presented completely and free from error (Kuye and Sulaimon, 2012).

The Literature on financial reporting system (FRCN,2011; Bansal and Sharma 2010) revealed that IFRS adoption has a significant impact on accounting and financial reporting functions. IFRS adoptions impacts across process and technology that will need to be factored into an organization's. The potential of IFRS requirements could drive changes in organization ICT compliance, consider the impact across transactional systems, financial instrument/investment valuation systems, product specific systems and interfaces that post financial transactions and reporting data. It is expected that while an IFRS renovation begins in accounting functions, to effectively create an integrated conversion strategy, a company should include the technology function. This change presents an opportunity quality and addressing improvements in business process and financial reporting systems (Frijat, 2013).Evidence from past studies (Tilahunm, 2019;Ghasemi, Shafeiepour, Aslani and Barvayeh, 2011; Oladejo and Yinus, 2014) showed that adoption of an accounting information system can be determined by a number of independent or explanatory variables like chief executive officer innovativeness, management commitment, and perceived ease of use, human resource and perceived complexity of accounting information system, benefit of the system, level of risk attached to the system and machinery cost. Human Resource Human resources are most likely to be core sources of continuous competitive advantage of organizations. Based on the studies Tilahunm (2019) there is a positive relationship between human resource and adoption of accounting information system in the hospitals of Jordan. More so, Perceived ease of use is one of the most important factors in explaining accounting information technology adoption and has a significant effect on the intention to use information systems, as observed by Tilahunm (2019. Oladejo (2014) was of the opinion that bank size, cost of technology usage and perceived benefit are considered variables for adoption and implementation technology system by the Nigeria banking sector. All these determinant factors of accounting information system adoption were evaluated as suggested in previous researches.

The concept of quality in the accounting system of the Nigerian banks is not entirely new, but the problem is that it is not well articulated and demonstrated. In spite of the accounting software availability, the banking industry still cannot meet up with the demands of the users (Dandago and Rufai, 2014). This gives an avenue for further research and development on technology deployment. The report of Siriyama, (2017) on financial reporting quality in Atlanta, the United States as one of the developed country form opinion that the widespread failure in the financial information quality has created the need to improve the financial information quality. In line to this, the deployment of accounting technology and the extent to which accounting technology can serve as an instrument of financial information quality improvement need to be examined in a developing country like Nigeria. Evidence from the literature (IASB, 2008; Healy, Paul and Palepu, 2001) shows that despite the interventions of the regulatory authorities, the challenges of ensuring credibility in financial reporting 
are still prevalent. More so, despite the advent of accounting technology, banks today faced with the issue of how well to actualized financial reporting quality and limited attention has been given regarding the issues as observed by Shargari, Abudullah and Saat (2015) in Nigeria.

The determinant factors of e-accounting adoption financial of selected deposit money and the extent to which the use of e-accounting practices can improve financial reporting quality and value relevance on the financial statement of banks are worthy of exploration in the Nigerian context.

\section{Research Hypotheses}

$\mathbf{H O}_{1}$ : There is no significant difference in factors influencing the adoption of an e-accounting system in the selected deposit money banks in Nigeria

$\mathbf{H O}_{2}$ : E-accounting do not significantly promote financial reporting quality of selected deposit money banks in Nigeria

\section{CONCEPTUAL FRAMEWORK}

\subsection{Information System}

The information system is a system that generates information for the user; for example, accounting information system generates financial reports information used for decision-making by parties accounting information (AzharSusanto, 2009). The main objective of the information system is to contribute to the organization so that it can operate effectively and efficiently (Bagranoff, Simkin and Norman, 2011). Opinions and Maracas (2010), defines the information system as a combination that has been set up consisting of human, hardware, software, network communications, data sources, policies and procedures to store, recover, transform and disseminate information to within the organization. From the above opinion can be concluded that the information system itself is a collection of parts (elements) that interact with the intended change (transform) data into useful information for the organization, such as financial transaction data that is processed into the financial statements. Generally, the data are processed in information systems is the data relevant to the activities of the organization that is useful for users who are in the organization.

\subsection{Financial Reporting Quality}

Horngren, Sundem, Stratton, Burgstahler and Schatzberg(2011), define financial reporting as a process of identifying, measuring, accumulating analyzing, preparing, interpreting, and communicating information to the user groups. The financial statements provide information about the assets, debt and other transactions or events that result in changes to the assets and debts. Financial reporting according to Higson (2003) can be interpreted as a form of dealing with things that generate accounting data and communicate the data to outside parties with interest in the company's financial reporting. Jacob and Madu (2009) believed that financial reporting is a system that records and summarizing business and financial transactions, analyze and verify and report the results. According to Elliot and Elliot (2011), financial reporting is the provision of financial information about the reporting entity that can be used for current and potential investors at the time of decision-making and reporting assessment.

Financial information that can be compared with similar companies can increase the value of the information itself as observed by Romney, (2010). Perhaps that is whyKieso, Weygandt, and Warfield (2011) argued that quality financial information must meet certain requirementssuch as relevance, completeness and timeliness. A quality accounting information should promoteunique decision and honest presentation that match the number and description of the existing reality.

Olakunori (2009) posits that to achieve the basic objectives of financial reporting, there is a need for an acceptable coherent framework. The financial framework therefore, refers to fundamental accounting assumption, principles and methods used to prepare, present and report financial statements for a wide variety of entities including publicly traded and privately held companies , nonprofit organizations, and governments. The framework for financial reporting include locally applicable accounting laws, regulations, rules and standards, that are determined by regulatory authorizes such as the Nigerian accounting standard board (NASB), which operates under a set of assumption, principles, and constraints. According to Yusuf (2006), accounting frame, which is 
commonly described as Generally Accepted Accounting Principles (GAAP), should not be seen as a constitution but a mere guideline to the preparation of financial statements.

\subsection{Accounting Systems and Value Relevance}

Accounting provides financial information about a business or a not-for-profit organization. Owners, managers, investors and other interested parties need financial information for decision making. Financial accounting is the art of systematically identifying, measuring, recording, classifying and summarizing in a significant manner and in terms of money, transactions, and events which are, in part at least, of financial nature, and communicating, analyzing and interpreting the results thereof (Woode and Sangster, 2008). Evidence from the literature shows that financial accounting as an organizational function aims at measuring, processing and communication financial information, which is crucial for business success as well as organization for effective decision making.

The concept of value relevance originates from the idea of whetheravailability of accounting information is useful to investors when making investment decisions. Observations in the last two decades indicate an increase of interest in connecting accounting numbers to market value. The main emphasis in value relevance literature is to empirically examine if financial statement variables can explain the variability in capital market variables. If there exists a relationship, measures are made to interpret how much of the variation in the dependent stock market variable is explained by the independent accounting variables (Beaver, 2002).

Several researchers describe accounting information as value relevant if it significantly relates to equity market value (Ohlson, 1995; Barth, 2001; Beaver, 2002). Earlier studies relate the value relevance of accounting information to investor's behaviour and the change in behaviour. More extensively and recent studies relate value relevance to firm value. Francis and Schipper (1999) stated that value relevance is the accounting information's ability to determine a firm's value.

\subsection{Manual Accounting System and its Shortcomings}

Manual accounting system is an information system and according to Romney and Steinbart (2009) an information system organized means of collecting, entering, and processing data and storing, managing, controlling, and reporting information so that an organization can achieve its objectives and goals. Manual accounting implies that employees perform the whole accounting cycle manually on a periodic basis including drafting trial balances, journalizing transactions, and preparing financial statements.The advantages of manual accounting systems include comparative cheap workforce and resources, reliability, independence from machines, skilled workers availability. However the manual system is criticized for reduced speed, increased workload of accountants, relatively slower internal control reporting, routine work and the issue of backups.

\subsection{Electronic Accounting Systems}

The concept of electronic accounting system is evolving and broadening as new development brings change to accounting due to technology. Electronic accounting system advances from a narrow focus on computer-based accounting to a broader concept of applying online, mobile and internet technologies in performing accounting functions. A review of the literature on the practice of eAccounting shows that computer-based accounting system and accounting information system are being used in describing electronic accounting (Amidu, Effah and Abor, 2011). However, there are differences in the use of these terms on the basis that advancements in technology will continually broaden the scope of e-Accounting. For instance, Amiduet al. (2011) described electronic accounting as an accounting system that relies on computer technology for capturing and processing financial data in organizations. Conceptualizing e-Accounting to connote the application of computer technology in capturing an organization financial data might give it a narrow meaning. The reason is that it makes no recourse to other technologies.Tijani and Mohammed (2013) define e-Accounting as a system that is significantly enabled by computer technology designed in accordance with techniques relevant to achieve qualitative decision-making objectives of the business.

Muhrtala and Ogundeji (2013) describe e-Accounting as a system that handles both financial and nonfinancial transactions that directly affects the processing of financial transactions. However, in the context of this study, e-Accounting refers to any accounting system that utilizes ICT applications tools 
and devices in gathering, recording, analyzing, processing, interpreting, communicating accounting transactions and information concerning economic events to enable stakeholders to make informed decisions. Having conceptualized the term e-Accounting, the study captured the presence of an eAccounting system based on one or all of the following platforms; the use of spreadsheets, accounting software, and web-based accounting.

Electronic Accounting Systems follow the same logic of journal, ledgers, reports, and statements in a manual system. E- Accounting systems simply consolidate posting functions and other basic tasks into a behind the scenes system. Companies can also generate reports and financial statements easier, allowing for better performance management reviews. Electronic Accounting Systems is, therefore, a computer-based system which combines accounting principles and concepts as well as the concept of an information system to record, process, analyze and produce financial information to its users for making economic decisions (Gelinas, Sutton and Hunton, 2005).

\subsection{Theoretical Framework}

There are several theories that may form the bedrock upon which this study may be based. While some are well known in research, a few of them too are based largely on perceptions. Theconstruct of this study will be based on Refined Technology Acceptance Model (RTAM) and Information Theory (IS). This is based on the fact that Venkatesh (1996) modified TAM and posit that perceived ease of technology usage and perceive usefulness oftechnology as determinants toward adoption and usage. An individual may adopt a technology if he or she perceives it as convenient, useful and socially desirable even though they do not enjoy using the technology.More so, quality of financial information is seen as a means to determine the value relevance of accounting information. Financial report quality is also valued as a means of improving the financial data used in decision- making.

\subsection{Empirical Review}

Based on the review of most related studies like Dandago and Rufai (2014) that examined information technology and accounting information system in the Nigerian banking industry, Onaolapo and Odetayo (2015) that examined the effect of accounting information system on organizational effectiveness and Oladejo (2014) that assessed E-Accounting Practices in the Nigerian Deposits Money Banks in Nigeria, it is pertinent to present the identified gaps filled by the current study. In the first instance, all these identified studies made use of judgmental sampling technique to select their sample and none of these authors specified on the type of judgmental technique adopted. However, there are various types of judgmental sampling in which this present study filled a gap with the use of homogeneous purposive sampling techniques to select the sampled banks for the study in Lagos state, Nigeria.

Studies on determinant factors electronic accounting usage like Sekyereet al. (2017) identifycertain determinants variables of the computerized accounting system variables such as perceived usefulness, perceived ease of useand its effect on the accurate financial report in listed banks in Ghana. Likewise, Munasinghe (2015) identify business size, cost and external environment as major influencing factors for the use of the electronic accounting system by SMEs in North Central Province. The issue in this regard needs to be well explored because certain specific factors that influence technology adoption in one country may not work in another country based on geographical differences according to Stefefano, (2006). The extent to which all evaluated determinant factors for technology adoption and usages such as perceived usefulness, perceived ease of use, cost of technology deployment, bank size and others can be considered as factors influencing electronic accounting practices constitute another gap filled by this study.

In another study,Ariff, Loh, and Chew (1997) posit a relationship between earnings and share prices. It was of the opinion that the major reason for which accounting information is produced is to facilitate quality reporting system and effective decision making. The method of actualizing appropriate accounting information system and the extent to which it influences financial information value relevance form gap filled by this present study. Also worthy of further empirical analysis is the submission of Amveko (2011) that computerized accounting system actually has an influence on the quality of financial reports for publication purposes but the extent to which computerized accounting 
practice influence value relevance of financial information for publication purposes was not explored which thus form a gap filled by this present study.

Further, having looked at different literature like (Try and Evita, 2015; Sekyereet al. 2017) on electronic accounting practices,user confidence in accounting information and financial reporting quality. The variables of their studies were measured based on perception and expected qualitative characteristics of financial report quality. Whereas this present study makes an expression on both quantitative and qualitative characteristics of electronic accounting practice and financial report quality that will enhance the user's confidence in the financial statement of selected deposit money banks in Nigeria.

Table1.ShowingEmpirical Research on Related Studies

\begin{tabular}{|c|c|c|c|}
\hline Authors & Research Objectives & Sampling and Countries & Main Findings \\
\hline $\begin{array}{l}\text { Akesinro and } \\
\text { Adeteso (2016) }\end{array}$ & $\begin{array}{l}\text { the effect of computerized } \\
\text { accounting system on the } \\
\text { performance of banks in } \\
\text { Nigeria }\end{array}$ & $\begin{array}{l}\text { Questionnaires were } \\
\text { administered on the staff of } \\
\text { three selected banks of } \\
\text { Nigeria and Analyzed through } \\
\text { Correlation }\end{array}$ & $\begin{array}{l}\text { Findings show that computer } \\
\text { accounting system has } \\
\text { increased patronage of banks } \\
\text { customers. }\end{array}$ \\
\hline $\begin{array}{l}\text { Dandago and } \\
\text { Rufai (2014) }\end{array}$ & $\begin{array}{l}\text { Information Technology } \\
\text { and Accounting } \\
\text { information } \\
\text { a system in the Nigerian } \\
\text { banking industry }\end{array}$ & $\begin{array}{l}\text { Both primary and secondary } \\
\text { data wereused, and the } \\
\text { Analysis of Variance } \\
\text { (ANOVA) was used to test } \\
\text { the hypothesis. Judgmental } \\
\text { sampling } \\
\text { a method was used to obtain a } \\
\text { representative sample of the } \\
\text { population of selected deposit } \\
\text { money bank through NSE } \\
\text { book Fact. }\end{array}$ & $\begin{array}{l}\text { Finding shows that } \\
\text { accounting } \\
\text { information technology is } \\
\text { relevant in simplifying issues } \\
\text { and in the provision of quality } \\
\text { information } \\
\text { in the Nigerian banking } \\
\text { industry }\end{array}$ \\
\hline $\begin{array}{l}\text { Munasinghe } \\
\text { (2015) }\end{array}$ & $\begin{array}{l}\text { factors influence on the } \\
\text { usage of computerized } \\
\text { accounting system on small } \\
\text { and medium scale } \\
\text { enterprises }\end{array}$ & $\begin{array}{l}\text { a structured questionnaire was } \\
\text { specially designed for the } \\
\text { study and employed in data } \\
\text { collection }\end{array}$ & $\begin{array}{l}\text { The study concluded that } \\
\text { factors such as business size, } \\
\text { cost, and external } \\
\text { environment are significantly } \\
\text { influenced the use of CASs } \\
\text { by SMEs and all other } \\
\text { variables are such as } \\
\text { infrastructure, government } \\
\text { support, perceived ease of use } \\
\text { and management support are } \\
\text { insignificant. }\end{array}$ \\
\hline Oladejo (2014) & $\begin{array}{l}\text { An Assessment of E- } \\
\text { Accounting Practices in the } \\
\text { Nigerian Deposits Money } \\
\text { Banks }\end{array}$ & $\begin{array}{l}\text { A survey methodology using } \\
\text { a sample of purposively ten } \\
\text { selected DMB in Nigeria and } \\
280 \text { staff were randomly } \\
\text { administered. }\end{array}$ & $\begin{array}{l}\text { It was concluded that e- } \\
\text { accounting would } \\
\text { significantly improve } \\
\text { accounting procedures in the } \\
\text { Nigerian banks }\end{array}$ \\
\hline $\begin{array}{l}\text { Onaolapo and } \\
\text { Odetayo } \\
(2015)\end{array}$ & $\begin{array}{l}\text { the effect of accounting } \\
\text { information system on } \\
\text { organizational effectiveness } \\
\text { with special reference to } \\
\text { selected construction firms } \\
\text { in the Ibadan metropolis }\end{array}$ & $\begin{array}{l}\text { Purposive sampling technique } \\
\text { was adopted in selecting a } \\
\text { total of ten personnel from } \\
\text { each of the selected } \\
\text { companies in Ibadan, Nigeria }\end{array}$ & $\begin{array}{l}\text { The results show that } \\
\text { accounting information } \\
\text { system has an effect on } \\
\text { organizational effectiveness. }\end{array}$ \\
\hline
\end{tabular}




\begin{tabular}{|c|c|c|c|}
\hline $\begin{array}{l}\text { Sekyereet al. } \\
(2017)\end{array}$ & $\begin{array}{l}\text { determinants } \\
\text { computerized accounting } \\
\text { system on an accurate } \\
\text { financial report in listed } \\
\text { banks on the Ghana stock } \\
\text { exchange }\end{array}$ & $\begin{array}{l}\text { Descriptive cross-sectional } \\
\text { survey design involving } \\
\text { quantitative approaches was } \\
\text { employed for this study }\end{array}$ & $\begin{array}{l}\text { the study concluded that there } \\
\text { is a strong positive correlation } \\
(84 \%) \text { between Computerized } \\
\text { Accounting System and } \\
\text { accurate financial reporting. }\end{array}$ \\
\hline $\begin{array}{l}\text { Try and Evita } \\
(2015)\end{array}$ & $\begin{array}{l}\text { Financial reporting quality } \\
\text { before and after the } \\
\text { adoption of International } \\
\text { Financial Reporting Quality } \\
\text { (IFRS) }\end{array}$ & $\begin{array}{l}\text { Survey design among the } \\
\text { listed Indonesian companies }\end{array}$ & $\begin{array}{l}\text { It was concluded that } \\
\text { financial reporting quality } \\
\text { after IFRS adoption is higher } \\
\text { than before showing that } \\
\text { characteristics of relevance, } \\
\text { understandable and } \\
\text { comparability level increased } \\
\text { after IFRS adoption and yet } \\
\text { had a decreasing trend and } \\
\text { timely level of financial } \\
\text { reporting in the period before } \\
\text { and after IFRS Adoption. }\end{array}$ \\
\hline
\end{tabular}

Source: Author's Compilations, 2019.

\section{MeThodology}

Primary data were collected using questionnaire and secondary data covering a period of 2010-2017 from the annual report of the selected banks. The study population comprises of all fifteen (15) Deposit Money Banks currently operating in Nigeria as listed on the Nigeria Stock Exchange report (2018) out of which ten (10) were selected using homogeneous purposive sampling technique. The sampled banks were Zenith Bank Plc, Guarantee Trust Bank Plc, First bank Plc, UBA Plc, Eco bank, FCMB, Fidelity bank, Access Bank, Diamond bank and Union Bank Plc. The purposive choice of the sampled banks is based on the banks that were in existence and listed as at 31 December 2018 as well as banks that have not been taken over by other banks or changed their names between 2010 and 2017.The annual reports of sampled banks in Lagos state Nigeria, covering 2010-2017 were analyzed to achieve the objectives of the study. Lagos state was chosen based on the fact that all the selected banks have their headquarters in Lagos and the city is known to be at the forefront of economic activities.

Three hundred copies of a questionnaire were administered randomly on the selected staff of the banks out of which two hundred and sixty were returned and used for the study. Data collected were analysed using descriptive statistics like table and percentage with inferential statistics such as regression analysis. This is based on the fact that regression analysisestablishrelationship among variables and the extent to which one influence others.

\subsection{Model Specification}

\section{Model 1}

$\mathrm{MPS}_{\mathrm{it}}=\boldsymbol{\alpha}_{\mathrm{o}}+\boldsymbol{\alpha}_{1} \mathrm{BS}_{\mathrm{t}}+\boldsymbol{\alpha}_{2} \mathrm{OPE}_{\mathrm{t}}+\boldsymbol{\alpha}_{3} \mathrm{HR}_{\mathrm{t}}+e_{i t}$

Where:

BS- Bank operation size

OPE-cost of operating expenses

HR- Cost of human resources

MPS- Market Price Share

Evidence from literature discloses that there is little agreement among researchers about how best to measure financial accounting practices (Dechow, Ge, and Schrand 2009).Furthermore, kadiri and Ibrahim (2009) emphasized on the value relevance measurement in terms of book value and earnings. 
All these have prompted the adoption of Market Price Share (MPS) as an index for value relevance. Alsofinancial reporting quality (FRQ) was proxy based Market Price Share (MPS).

Further, Electronic accounting practice was measured through Bank size (BS), operating expenses (OPE) and Cost of Human Effort/ Human resource cost (HRC) of selected Deposit Money Banks. Evidence from pieces of literature (Agboola, 2006; Ayo, Ekong, Fatudimu and Adebiyi, 2007; Oladejo 2014) reveal that majorly today banks depend largely on ICT. Therefore Technology would have taken a substantial part of operation cost. Furthermore, human resources cost is described as cost of human activities that are skilful and personal which cannot be attached to ICT being more of brain supervisory work rather than digital work. For such, all staff salary and wages cannot be used as operating expenses.

\section{RESULTS AND DISCUSSION}

\subsection{Bankers' Perception of FactorsInfluencing the Adoption of E-Accounting in the Selected Sampled Deposit Money Banks of Nigeria.}

Table 2, shows the analysis of factors influencing e-accounting adoption in the selected sampled deposit money banks of Nigeria as elicited from bank workers. The result shows that $92.30 \%$ of the stakeholder of financial services such as bank workers opined that Bank size had a strong influence on e-accounting adoption. Also, 69.23\% of the respondent agreed that the Cost of ICT Deployment is one of the major factors affecting the adoption of the e-accounting system by the deposit money banks of Nigeria. $73.50 \%$ of the stakeholders opined that Perceived Ease of Use (PEU) is part of factor influencing the adoption of e-accounting in the Nigeria deposit money banks. The results overview revealed that $(85.66 \%)$ of the respondent believed that the perceived benefit of electronic accounting practices is the major determinant for adoption in the Nigeria deposit money banks. This result supports the argument of (Patel and Connolly 2015; Oladejo, 2014) that opined perceived benefits, Perceived Ease of Use were main factors encouraging adoption of new technology.

Table2.Factor influencing electronic accounting adoption in the selected deposit money banks

\begin{tabular}{|l|l|l|l|l|l|}
\hline Influencing Factors & Very High & High & Undecided & Low & No Influence \\
\hline Bank Size (BS) & $\begin{array}{l}195 \\
(75 \%)\end{array}$ & $\begin{array}{l}45 \\
(17.30 \%)\end{array}$ & $\begin{array}{l}- \\
-\end{array}$ & $\begin{array}{l}8 \\
(3.08 \%)\end{array}$ & $\begin{array}{l}12 \\
(4.62 \%)\end{array}$ \\
\hline $\begin{array}{l}\text { Cost of ICT } \\
\text { Deployment (CID) }\end{array}$ & $\begin{array}{l}170 \\
(65.38 \%)\end{array}$ & $\begin{array}{l}10 \\
(3.85 \%)\end{array}$ & $\begin{array}{l}80 \\
(30.77 \%)\end{array}$ & - & - \\
\hline $\begin{array}{l}\text { Perceived Ease of Use } \\
\text { (PEU) }\end{array}$ & $\begin{array}{l}57 \\
(21.09 \%)\end{array}$ & - & $\begin{array}{l}67 \\
(26.50 \%)\end{array}$ & - \\
\hline Perceived Benefit (PB) & $\begin{array}{l}(52.41 \%) \\
(78.51 \%)\end{array}$ & $\begin{array}{l}26 \\
(7.15 \%)\end{array}$ & $\begin{array}{l}10 \\
(3.05 \%)\end{array}$ & $\begin{array}{l}10 \\
(3.05 \%)\end{array}$ & $\begin{array}{l}14 \\
(5.18 \%)\end{array}$ \\
\hline
\end{tabular}

Source: Author's Computation (2019).

\subsection{Analysis of Differences in the Factors Influencing E-Accounting Practice Adoption in Nigeria Money Deposit Banks.}

Based on regression result presented in table 3, a unit increase in Bank Size increases e-accounting practice by 1.1 units, showing that Bank Size has a significant effect on E-accounting practice in the selected deposit money banks also increases adoption decision. The analyses indicate that eaccounting adoption is significantly related to Bank Size at 0.013 percent. On the other hand, a unit increase in the Cost of ICT Deployment reduces e-accounting by 1.2 units; this shows a negative effect between Cost of ICT Deployment and e-accounting adoption. The analyses indicate that eaccounting adoption is significantly related to Cost of ICT Deployment at 0.048 percent. Also, a unit increase in Perceived Ease of Use increases e-accounting adoption by 0.6 units, which signifies a positive significant relationship between e-accounting adoption and Perceived Ease of Use. This means that as Perceived Ease of Use of e-accounting banking service increases the adoption of eaccounting system increases. The analyses indicate that e-accounting adoption is significantly related to Perceived Ease of Use at 0.073 percent. Finally, a unit increase in perceived benefit increases eaccounting services by 8.6 , which show a high positive effect between e-accounting adoption and 
perceived benefit. The result is highly significant, and this indicates that the perceived benefit of eaccounting practice is a key determinant of e-accounting adoption in Nigeria Deposit Money Banks.

More so, results presented in table 3, with the coefficient of determination $\left(\mathrm{R}^{2}\right)$ of 0.9661 , Adjusted $\left(\mathrm{R}^{2}\right)$ at0.9633indicates that independent variables incorporated into this model have been able to explain the differences in factors influencing adoption of E-accounting practice in selected sampled deposit money banks in Nigeria. This is further supported by and F-Value of 1308.51 andP-Value (0.000). The constant and coefficients are statistically significant. Due to this result, the null hypothesis is rejected while the alternative hypothesis is accepted indicating the fact that there is a significant difference in factors influencing e-accounting adoption in Deposit Money Banks in Nigeria.

Table3.Regression Analysis of Differences in the factors influencing E-accounting Practice Adoption in Nigeria Money Deposit Banks.

\begin{tabular}{|c|c|c|c|c|}
\hline & Coefficient & \multicolumn{2}{|l|}{ Std.Err } & $\mathbf{P}>\{\mathbf{T}\}$ \\
\hline Bank Size (BS) & .1195591 & .0475475 & 2.51 & 0.013 \\
\hline Cost of ICT Deployment (CID) & -.1221378 & .0615585 & -1.98 & 0.048 \\
\hline Perceived Ease of Use (PEU) & .0650242 & .0362542 & 1.79 & 0.073 \\
\hline Perceived Benefit (PB) & .8628456 & 0503438 & 17.14 & 0.000 \\
\hline $\begin{array}{l}\text { Constant } \\
\mathbf{F}(\mathbf{4 . 2 5 5})=(\mathbf{1 3 0 8 . 5 1 )}\end{array}$ & -.071559 & .0869684 & -0.82 & 0.411 \\
\hline$F(4,255)=(1308.51)$ & $=0.000$ & 0.9661 & $\begin{array}{l}\text { AdjRsquared } \\
=0.9633\end{array}$ & $\begin{array}{l}\text { Root MSE }= \\
.27209\end{array}$ \\
\hline
\end{tabular}

Source: Authors Computations, (2019).

\subsection{Influence of E-accounting on Financial Reporting Quality of theSelected Deposit Money Banks in Nigeria.}

The result of the preliminary ordinary least squares regressions is displayed in Table 4 . The ordinary least squares regressions represent pooled OLS regressions since the variables are part of a panel data set. The result presented described the estimates of the model using MPS as a measurement for financial reporting quality specified in the study.The table further showed the estimates of explanatory variables, including operating expenses, human resource, and bank size, respectively.

The coefficient estimation revealed that a unit increase in operating expenses and bank size would reduce financial report quality through market value by (1.6unit, 13.3uints) respectively. Also, a unit increase human resource increases market value by 4.4 units. The analyses indicated that electronic accounting practice variables identified are significantly related to financial reporting at 0.05 significance level.

Table4.Pooled OLS Parameter Estimates Model

Variables: MPS, OPE, BS, HR

\begin{tabular}{|l|l|l|l|l|}
\hline Variable & Coefficient & StandardError & T-Test Values & Probability \\
\hline C & 8.555448 & 2.672088 & 3.20 & 0.002 \\
\hline OPE & $-1.68 \mathrm{e}-08$ & $1.50 \mathrm{e}-08$ & -1.12 & 0.026 \\
\hline HR & $4.40 \mathrm{e}-08$ & $4.43 \mathrm{e}-08$ & -0.99 & 0.004 \\
\hline BS & -.1331592 & .1891898 & -1.70 & 0.002 \\
\hline
\end{tabular}

$R$-square $=0.5235$, Adjusted $R$-square $=0.5151, F$-statistics $=1.61, \operatorname{Prob}(F$-stat $)=0.0001$

Source: Author's Computation (2019)

\subsubsection{Fixed Effect Estimation}

Fixed effects estimators are consistent where a long panel is involved and are preferred to random effects estimators, and if the individual error components and one or more regressors are correlated, then the random effects estimators are biased, whereas those obtained from fixed effects model are unbiased. Fixed effect model takes effect of the heterogeneity/uniqueness that may exist across the subject unit and/or over time, as such the model include fixed effect for each of the cross-sectional unit and/or a specific period. 
The report in table 5 revealed that electronic accounting practice variables identified are significantly related to financial reporting quality through market share price of selected banks and significant at 0.05 confidence level. More so, the results in table 5 with coefficient of determination $\left(\mathrm{R}^{2}\right)$ of 0.6203 (approximately 62\%) and Adjusted $\left(\mathrm{R}^{2}\right.$ ) of 0.6150 (approximately 62\%)indicated that independent variables incorporated into this model have been able to revealed that e- accounting practice positively influence user's confidence in the financial statement of the selected deposit money banks in Nigeria.

Table5.Fixed Effect Parameter Estimate Model

Series: MPSBS OPE HR

\begin{tabular}{|l|l|l|l|l|}
\hline Variable & Coefficient & Standard Error & T-Test Values & Probability \\
\hline C & 5.844946 & 1.267151 & 4.61 & 0.000 \\
\hline BS & .0997208 & .0906394 & 2.10 & 0.000 \\
\hline OPE & $-2.20 \mathrm{e}-09$ & $5.63 \mathrm{e} 09$ & -0.39 & 0.002 \\
\hline HR & $-2.23 \mathrm{e}-08$ & $-1.90 \mathrm{e}-08$ & -2.25 & 0.004 \\
\hline
\end{tabular}

$R$-square $=0.6201$, Adjusted $R$-square $=0.6150, F$-statistic $=67.20, \operatorname{Prob}(F-$ stat $)=0.0000$, Prob $>$ chi $2=0.0006$, Wald chi2 $(3)=22.19$

Source: Author's Computation (2019)

\subsubsection{Test of Heterogeneity}

The result in table 6 , presents a summary of test statistics conducted to validate the presence of heterogeneity effect among cross-sectional units and across time. The test set out to know whether there is a significant difference between the differential intercept across companies and time period and to validate whether the restriction of the pooled OLS estimation is justified. The result reported fstatistics values of 4.12 and 5.33 for pool OLS regression and Fixed effect regression, respectively. The probability values of the reported f-statistics $(0.0003 ; 0.001)$. Invariably, the results revealed that there is uniqueness in the characteristics of selected deposit money banks.

Table6.Test of Heterogeneity

\begin{tabular}{|l|l|l|}
\hline & F-statistics & Probability \\
\hline OLS & 4.12 & 0.0003 \\
\hline FE & 5.33 & 0.0001 \\
\hline
\end{tabular}

Source: Author's Computation (2019)

\subsubsection{Random Effect Estimation}

Evidence from literature reveals that because of the problems inherent in the fixed effect model such as loss of degree of freedom as more dummy variables are added to the model, possibility of multicollinearity, inability of the fixed effect model to track the impact of time-invariant variablesrandom effect may be employed. Random effect assumes that the heterogeneity is random rather than fixed and that the random effect is incorporated into the error term thus forming a composite error term.

The results presented in table 7 revealed that electronic accounting practices variables like bank size, operating expense positively influence financial reporting quality. Specifically, the table reported coefficient estimates of 0.140682 and $1.35 \mathrm{e}-08 \mathrm{Bank}$ size and operating expenses respectively. It is further shown that human resources influence financial report quality. A unit increase in human resource reduces financial report quality of the sampled banks. The result of R-square and Adjusted $R$ squarevalue of $(0.5166 ; 0.5106)$ also support the significance of the model.

Table7.Random Effect Estimation Model

Series: MPS OPE BS HR

\begin{tabular}{|l|l|l|l|l|}
\hline Variable & Coefficient & Standard Error & T-Test Values & Probability \\
\hline & 7.08037 & 2.401862 & 2.95 & 0.003 \\
\hline BS & .0140682 & .1482055 & 0.09 & 0.024 \\
\hline OPE & $1.35 \mathrm{e}-08$ & $9.61 \mathrm{e}-09$ & 1.41 & 0.059 \\
\hline HR & $-4.88 \mathrm{e}-08$ & $3.15 \mathrm{e}-08$ & -1.55 & 0.002 \\
\hline
\end{tabular}


Electronic Accounting Practices: An Effective Means for Financial Reporting Quality in Nigeria Deposit Money Banks.

$R$-square $=0.5166$, Adjusted $R$-square $=0.5106, F$-statistics $=11.68$, Prob $>$ chi $2=0.0075$, Wald chi2 $(3)=2.54$.

Source: Author's Computation (2019)

\subsection{Discussion of Results}

The results of the analysis revealed specific considered factors influencing electronic accounting adoption in the selected sampled deposit money banks such as Bank Size (BS), Cost of ICT Deployment (CID), Perceived Ease of Use (PEOU) and Perceived Benefit (PB). The results showed that there is a significant difference in the factor influencing the adoption of e-accounting. These results are supported by earlier studies of Munasingbe (2015), Padachi (2012),Sekyereet al. (2017) shedding light on e-accounting adoption variables and at different levels of their influence on eaccounting practices. Findings revealed that electronic accounting practice positively influence the financial reporting quality of selected sampled deposit money banks in Nigeria. These results corroborate the findings of Dandago and Rufai (2014), Odero (2014), Oladejo (2014), and Sekyereet al. (2017)that technology accounting practice will significantly improve accounting procedures and quality of financial statement presented by corporate organization.

\section{CONCLUSION AND RECOMMENDATIONS}

The study concluded that all the identified variables: Bank Size (BS), Cost of ICT Deployment (CID), Perceived Ease of Use (PEOU) and Perceived Benefit (PB) influenced e-accounting adoption and that e-accounting practice enhanced accounting procedure and improved the timeliness of report generation and financial reporting quality of banks.

In view of the above finding the following recommendations were made:

i. Management of Nigeria Deposit Money Banksare enjoined to put more effort by developing mechanism that strengthens e-accounting usage to promote users confidence on the financial information of banks .

ii. Collaboration among banks should be maintained by Nigeria deposits money banks in order to make electronic accounting spread across and meet the Quality of financial report needed by banks' Stakeholders.

\section{REFERENCES}

[1] Abeysekera, I. (2013). A template for integrated reporting. Journal of Intellectual Capital. 14(2): 227-245.

[2] Adeyemi, A. A. and Asaolu, T.A. (2014). An empirical investigation of the financial reporting practices and banks' stability in Nigeria. Journal of Business and Management ReviewSciencesKuwait Chapter of Arabian 4(1):145-156.

[3] Adeniyi, O.M. (2006). Bank Credit and Economic Development in Nigeria: A Case Study of Deposit Money Banks. University of Jos, Jos. (Unpublished)

[4] Adzis, A. A., Anuar, H. S., and Hishamuddin, N. M. (2015). Malaysian Commercial Banks: Do Income Smoothing, Capital Management, Signaling, and Pro-Cyclicality Exist Through Loan Loss Provisions. International Journal of Economics, Finance and Management, 4(1): 1-9.

[5] Agboola, A. A (2006). Electronic payment systems and Tele banking services in Nigeria. Journal of Internet Banking and commerce 11 (3):47-51

[6] Akesinro and Adetoso (2016). The effect of computerized accounting system on the performance of banks in Nigeria. Journal of economics and sustainable developments, 7(14):127-131.

[7] Akinduko, A.O. (2000). Basic Accounting.Akure, Spetins Nigeria Limited.

[8] Alamin, A. Y., William, W. M. and Salzman, S. (2015). An Empirical Study of Factors Influencing Accounting Information Systems Adoption. Completed Research Papers. Paper 3.ISBN 978-3-00-050284-2.

[9] Amidu, M., Effah, J., and Abor, J. (2011). E-Accounting practice in small and medium enterprise in Ghana. Journal of Management Policy and Practice, 12(4): 127-132.

[10] Amveko, A. (2011). Computerized Accounting Systems and Financial Reporting, unpublished B.s, Makerere University, Kampala.

[11] Anao, A.R. (2002). An Introduction of Financial AccountingLagos, Longman Nigeria Limited.

[12] Ariff, M., Loh, A. L. and Chew, P.M. (1997). The Impact of Accounting Earnings Disclosures on Stock Prices in Singapore, Asia Pacific Journal of Management, 14(1): 231-239. 
[13] Ayo, C., Ekong, U. O., Fatudimu, I.T. and Adebiyi, A. (2007). M-Commerce implimentation in Nigeria: Trends and Issues".,Journal of Internet banking and Commerce, 12(2):34-41.

[14] Azhar, S. (2009). Information Systems Management: Structured Approach, Risk, Development. Lingga Jaya: Bandung.

[15] Bagranoff, N, A., Simkin, M, G., and Norman, C, S. (2010). Core Concept of Accounting Information System. Eleventh Edition. John Wiley \& Son, Inc., USA.

[16] Bansal, S. C. and Sharma, L.A. (2010). New Challenges of Accounting and Auditing in Environment in India, RevistaUniversoContábil, 5(1):88-99

[17] Barth, M. E., Beaver, W.H, and Landsman, W.R. (2001). The relevance of the value-relevance literature for financial accounting standard setting: another view. Journal of Accounting and Economics 31(1-3): 77104.

[18] Barth, M. E., Landsman, W.R., and Lang, M.H. (2007). International Accounting Standards and Accounting Quality. Working Paper.

[19] Beaver, W. H. (2002). Perspectives on recent capital market research', The Accounting Review, 77: 453474.

[20] Bhatt, P. and Sumangla, J. K. (2012). Impact of earnings per share on market value of equity share: An empirical study in Indian Capital Market. Journal of Finance, Accounting and Management, 3(2): 127-131.

[21] Bukenya (2014). Quality of Accounting Information and Financial Performance of Uganda's Public Sector.American Journal of Research Communication. 2(1), PP. 183-203.

[22] Cooper, R. B. and Zmud, R. W. (1990). Information technology implementation research: A technological diffusion approach. Management Science, 36(2): 123-139.

[23] Corrocher, N. (2002) "Does Internet banking substitute traditional banking? Empirical Evidence from Italy”, Working Paper LucigiBocconi” No 134, UniversitaCommerciale,

[24] Dandago, K.I. and Rufai, A. S. (2014). An examination into the quality of audited financial statements of money deposit banks in Nigeria. International Journal of Academic Research in Accounting, Finance and Management.vol. 4(1): 145-156.

[25] Dechow, P., Ge, W. and Schrand, C. (2009). Understanding earnings quality: a review of the proxies, their determinants and their consequences. Journal of Accounting Econometrics. 50 (2), 344-401.

[26] Dechow, P. and Schrand, C. (2004). Earnings quality. The Research Foundation of CFA Institute.

[27] Delloite, A.W. (2013). IFRS transition - Navigating complexities. Delloite Global Services Limited, Partners in Learning.

[28] Emmanuel, O. W. (2015). Computerized Accounting System an Effective Means of KeepingAccounting Records in Ghanaian Banks: a Case Study of the GaRural Bank. International Journal of Research in Business Studies and Management2(11): 111-141.

[29] Francis, J. and Schipper, K. (1999). Have financial statements lost their relevance? Journal of Accounting Research 37(2): 319-352.

[30] FRCN (2011).The Financial Reporting Council of Nigeria Act.

[31] FRCN (2012).The Financial Reporting Council of Nigeria Act.

[32] Frijat, Y. (2013). The Impact of Accounting Information Systems Used In the Income Tax Department on the Effectiveness of Tax Audit and Collection in Jordan" Journal of Emerging Trends in Economics and Management Sciences, 5(1):19-25.

[33] Galaen, A. and Stenhaim, T. (2010). Differences in accounting quality between Norwagian GAAP and IFRS. A master thesis submitted to Buskend University College, spring, Norway.

[34] Gelinas, U.J, Sutton, S.G and Hunton, J. E. (2005). Accounting information systems. 6th edition. Thomson, OH, USA: South-Western.

[35] Ghasemi, M., Shafeiepour, V., Aslani, M., and Barvayeh, E. (2011). The Impact of Information Technology (IT) on Modern Accounting Systems.Procedia-Social and Behavioral Sciences, 28(15): 112116.

[36] Grande, E., Estébanez, R..andColomina, C. (2011). The impact of Accounting Information Systems (AIS) on performance measures: empirical evidence in Spanish SMEs", The International Journal of Digital Accounting Research, 11(3): 25 - 43.

[37] Hall, B. H. (2011). Measuring the Returns to R\&D. In Hall, B. H. and N. Rosenberg, Handbook of the Economics of Innovation, pp. 1034-1076.

[38] Higson, A. (2003). Corporate Financial Reporting: Theory \& Practice. London: SAGE Publications 
[39] Horngren, C. T., Sundem, G. L., Stratton, W. O. and Schatzberg, B.J. (2011). Introduction to Management Accounting. Fifteenth Edition. Pearson Education, Inc: New Jersey.

[40] IASB (2008). Exposure Draft on an improved Conceptual Framework for Financial Reporting: The Objective of Financial Reporting and Qualitative Characteristics of Decision-useful Financial Reporting Information. London.

[41] Irechukwu, G., (2000). Enhancing the Performance of Banking Operations through Appropriate Information Technology, Information Technology in Nigerian Banking Industry, Spectrum Books, Ibadan: 63-78.

[42] Kadri, M., Abdul Aziz, R. and Ibrahim, M. (2009). Value relevance of book value and earnings: Evidence from two different financial reporting regimes.

[43] Kam, V. (1990). Accounting theory (second edition). New York: Wiley.

[44] Khalid, M. S. (2004). Evaluation of Performance of Computer-Based Accounting Information Systems and their extent of appropriateness to fulfill management needs, unpublished Master thesis, Yarmouk University, Irbid, Jordan.

[45] Kieso, D, E., Weygandt, J,J. and Warfield, T, D. (2011). Intermediate Accounting. Volume 1. IFRS Edition. John Wiley and Sons, Inc:USA.

[46] Knaup, M. and Wagner, W. (2012). A Market-Based Measure of Credit Portfolio Quality and Banks' Performance during the Subprime Crisis. Management Science, 58(8): 1423-1437.

[47] Kuye and Sulaimon( 2012). Financial controls and firms' performance in the manufacturing sector in Nigeria; International Journal of Business Excellence.5(1/2):155 - 167.

[48] Lobo, G. J. (2017). Accounting research in baking - A review. China Journal of Accounting Research, 10(3): 1-7.

[49] Madawaki, A. (2012). Adopting International Financial Reporting Standards in Developing Countries: The Case of Nigeria: International Journal of Business and Management. 7 (3):121-126.

[50] Marivic, A. (2009). Evaluating the security of computerized accounting information systems. An empirical study on Egyptian banking industry, PhD. Thesis. Aberdeen University, UK

[51] Memis, M. U. (2011). E-Accounting: An Evaluation on the Turkish Case. European Journal of Economics, Finance and Administrative Sciences, 16(38): 155-163.

[52] Odero, A. (2014). The Effect of Accounting Information System Quality on Financial Performance of SmesIn Nairobi County" Master Degree, University of Nairobi School of Business. (Unpublished)

[53] Ohlson, J. A. (1995). Earnings, book values, and dividends in equity valuation. Contemporary Accounting Research 11(2):661-687.

[54] Okwo, Mbajiaku and Ugwunta (2012). Effect of deposit money ban credit on economic growth. International Journal of Current Research, 4(12): 555-559.

[55] Oladejo M.O. andYinus S.O. (2014). Effect of Payment Technology on Service Delivery in the Nigerian Microfinance Banks. International Journal of Managerial Studies and Research (IJMSR), 2(6),10-18.

[56] Oladejo, M. O. (2014). An Assessment of E-Accounting Practices in the Nigerian Deposits Money Banks. International Journal of Computer Science and Technology, 5(2): 121-127.

[57] Olakunori, D. (2009). financial reporting framework. American economic review, 93(1): 114-119.

[58] Onaolapo, A. and Odetayo, T. (2015). Effect of Accounting Information System on Organisational Effectiveness: A Case Study of Selected Construction Companies in Ibadan, Nigeria",American Journal of Business and Management, 1(4):183-189.

[59] Padachi, K. (2012). Factors affecting the adoption of formal accounting systems by SMEs. Business and Economics Journal, 3(7): 1-20.

[60] Pallai, C..S (2007). Qualities of Financial Reporting. Retrieved on March, 6, 2011.

[61] Paul, H. M. and Krishna, G. P. (2001) .Information asymmetry, corporate disclosure, and the capital markets: a review of the empirical disclosure literature, Journal of Accounting and Economics, 3(1):405440.

[62] Muhrtala, T., and Ogundeji, M. (2013). Computerised accounting information systems and perceived security threats in developing economies: The Nigeria case. Universal Journal of Accounting and Finance, 1(1): 9-18.

[63] Munasinghe, P. G. (2015). Factors influence on usage of computerized accounting system on small and medium scale enterprises. https://www.researchgate.net/publication/293172935

[64] Porter, G, A. and Norton, C, L. (2011). Using Financial Accounting Information: The Alternative to Debits and Credits. Seventh Edition. South-Western Cengage Learning: USA Viii / 3. 
[65] Romney, B. M. (2009). Accounting Information System, Twelfth Edition. Pearson Education Limited: England

[66] Romney, M., and Steinbart, P. (2012). Accounting informationsystems, 12 thed.

[67] Jacob, R.A.,and Madu, C.N. (2009). International financial reporting standards: an indicator of high quality. International Journal of Quality \& Reliability Management, 26(7): 712-722

[68] Schipper, K.S. (2007).Required disclosures in financial reports. The Accounting Review: 82 -90.

[69] Sekyere, Amoateng and Frimpong (2017); the determinants of computerized accounting system on accurate financial report in listed banks on the ghana stock exchange. International Journal of Finance and Accounting, 6(4): 104-110.

[70] Shargari, Abudullah and Saat (2015) : the Influence of System Quality and Informationqualty on acconting information system effectiveness in Nigeria bank. International post graduate journal, 7(2):5874.

[71] Siriyama, K. H. (2017). Financial Reporting Quality: A Literature Review.International Journal of Business Management and Commerce, 2(2): 372-379.

[72] Stefanou, C., (2006), The Complexity and the Research Area of AIS, Journal of Enterprise Information Management, 19(1), pp. 9-12.

[73] Tijani, O. M., and Mohammed, A. K. (2013). Computer-based accounting systems in small and medium enterprises: Empirical evidence from a randomized trial in Nigeria.Universal Journal of Management, 1(1): 13-21.

[74] Try, E. and Evita. O. (2015). International Financial Reporting Standard and Value Relevance of Accounting Information in Quoted Cement Firms in Nigeria. International Journal of Sciences: Basic and Applied Research, 6(3): 345-349.

[75] Venkatesh, V. and Davis, F. D. (1996). A Model of the Antecedents of Perceived Ease of Use: Development and Test, Decision Sciences, 27 (3), 451-481.

[76] Yen, S. and Nuraini, S. (2016). Value Relevance of Accounting Information: Evidence from Indonesia. The Social Sciences, 11(4): 7568-7573.

Citation: Oladejo, M.O \& Yinus S.O. "Electronic Accounting Practices: An Effective Means for Financial Reporting Quality in Nigeria Deposit Money Banks" International Journal of Managerial Studies and Research (IJMSR), vol 8, no. 3, 2020, pp. 13-26. doi: http:// dx.doi.org/10.20431/2349-0349.0803002.

Copyright: (C) 2020 Authors. This is an open-access article distributed under the terms of the Creative Commons Attribution License, which permits unrestricted use, distribution, and reproduction in any medium, provided the original author and source are credited. 